\title{
Illusory or effective? The protection provided by the Romanian authorities to stray dogs
}

Tatiana-Lăcrămioara Șoldănescu

Ph.D. Student in European human rights law Faculty of Law, University of Bucharest

\begin{abstract}
The problem that Romania has with stray dogs' management is well known at national level, but also intensely debated internationally. The main accusation brought against Romania is the authorities' noncompliance with the principle of minimum suffering. With the sole purpose of eliminating dogs from the streets, these authorities ignore any principles and recommendations that focus on animal protection. The legislative framework adopted without prior documentation seeks to propose superficial "solutions" with short-term effect, which divert attention and prevent awareness of the serious problem Romania and Romanians face. Romania is already harshly condemned for its national legislation and its unfortunate consequences, so we intend to understand the justification for this conviction based on the analysis of animal protection and management of stray dogs concepts.
\end{abstract}

Key words: stray dogs, animal protection, euthanasia, ill treatment, cruelty, legislation

Iluzorie sau efectivă? Protecția prevăzută de autoritățile din România pentru câinii fără stăpân

Rezumat: Problema pe care România o are în gestionarea câinilor fără stăpân este foarte bine cunoscută la nivel național, dar și foarte intens dezbătută la nivel internațional. Principala acuzație adusă României este nerespectarea principiului minimei suferințe de către autoritățile cu atribuții în gestionarea câinilor fără stăpân, care, având ca unic scop eliminarea câinilor de pe străzi, ignoră orice principii și recomandări pentru ca această activitate să aibă în centru protecția animalelor. Cadrul legislativ adoptat fără o documentare prealabilă caută să propună "soluții" superficiale, cu efect pe termen scurt, care distrag atenția de la importanța conștientizării gravei probleme cu care România și românii se confruntă. România este deja condamnată aspru pentru legislația națională și consecințele nefericite ale acesteia, astfel că ne propunem să înțelegem justificarea acestei condamnări plecând de la analiza conceptelor de protecție a animalelor și gestionare a câinilor fără stăpân.

Cuvinte-cheie: câini fără stăpân, protecția animalelor, eutanasiere, rele tratamente, cruzime, legislație 


\section{Issues regarding the treatment applied to stray dogs}

The situation of stray dogs and the need (or not) to protect them is a sensitive issue that has generated divided opinions from both dog lovers and advocates of eradicating them from the streets. Both sides have good reasons to support their cause: animal lovers invoke in the defense of non-speakers the illegality and immorality of killing stray dogs, while those who want dogs to disappear from the streets invoke the risk of their existence for their life, physical integrity and health.

The many tragic events caused by the attacks of stray dogs that resulted in even human deaths, along with emotional debates, but lacking documentation and legal basis, tip the scales in favor of killing dogs, without addressing the cause of the large numbers of stray dogs. This ignorance and lack of awareness of the real problem lead to an apparent solution by applying cruelty practices, which violate any moral and legal principles regarding the protection of stray dogs.

In the recent years, the media has reported numerous cruelty practices against dogs, with and without owners, acts performed by both citizens and local authorities. Cases of cruelty against dogs are widely reported in the press, but the statistics date from 7-10 years ago. In order to understand the bigger picture of these cases, we quote the response of the General Inspectorate of Police at the request of an association for animal protection: "in 20112013, 879 serious cases of cruelty against animals were identified by the police and charged (...) 387 cases were prosecuted. At the same time, in the last 4 years, 290 sanctions penalties by fine were applied for violations of the Law of Animal Protection"1. According to another statistic quoted in the explanatory memorandum of a $2017 \mathrm{draft}$ law amending the legislation on animal protection", "2-3 cases of animal abuse, torture and mutilation are registered daily and in a single year over 900 animals have been brought to shelters with their limbs cut off, starved to death or shot. (...) Another 542 complaints of abuse were submitted to the authorities $^{\prime \prime}$. Also, according to the Government Emergency Decree no. 175/2020 explanatory memorandum", "In the first 8 months of 2020, at the level of the Romanian Police structures, a number of 683 criminal acts were reported under Law no. 205/2004, an increasing number compared to the first 8 months of 2019 when their number was 491." Until the release of this document, no other official statistics could be identified. This lack of official statistics suggests that the authorities lack interest in this issue, at least until now, as will be seen further.

Animal lovers and associations working in the field of animal rights claim that apart from cases of cruelty leading to the maltreatment and torture of animals, physical and mental sufferings, there are also cases of killing using cruel methods, which manifestly violates the principle of minimum suffering.

\footnotetext{
${ }^{1}$ Andrei Călin, România, campioana actelor de cruzime îndreptate împotriva animalelor, published on 7 October 2013, available at https://www.animalzoo.ro/romania-campioana-actelor-de-cruzime-indreptate-impotrivaanimalelor/ (last accessed on 31 January 2021).

${ }^{2}$ Available at http://www.cdep.ro/caseta/2017/06/27/pl17244 se.pdf (last accessed on 31 January 2021).

${ }^{3}$ According to a press article - Mihaela Pavnutescu, România, iadul animalelor. Zilnic se înregistrează 2-3 cazuri de maltratare, published on 15 February 2011 - the statistics were carried out in 2010 by Green Report with the help of associations for the protection of animal rights. The article is available at https://www.greenreport.ro/romania-iadul-animalelor-zilnic-se-inregistreaza-2-3-cazuri-de-maltratare/ (last accessed on 31 January 2021).

${ }^{4}$ Available at Guvernul României (gov.ro) (last accessed on 31 January 2021).
} 
Therefore, the criticism of those who protect animals, the press debates on the acts of cruelty carried out on animals without owner, the failure to carry out procedures for the registration of such dogs which makes it impossible to identify them, the lack of monitoring the population of stray dogs, together with the lack of official statistics carried out on a regular basis and that are accessible to the public, all of these aspects result in a lack of institutional transparency.

The debate generated by the protection of stray dogs, amplified by the media attention given to this subject, should not lead to ignoring the protection of which the animals with owner also benefit from, starting from the wrong assumption that the latter are protected by their owners. These animals are also subject to acts of cruelty performed by their owners or other persons, including authorities that practice the mass killing of animals with methods that do not comply with the principle of discrimination. ${ }^{5}$

Animal rights advocates generally agree that all animals must be protected against cruelty and mistreatment, since they enjoy several fundamental rights. However, effective protection of animals from mistreatment must be achieved by means of legislation prohibiting intentional or negligent manifestations of animal mistreatment and imposing sanctions for acts that constitute cruel treatment against animals.

Thus, overcoming the intense and emotional debates on animal protection, often aroused by the approach of the subject in the press, this article aims to analyze the following aspects: the national, international and European legal framework on stray dogs (their management, obligations of authorities and individuals, protection of stray dogs); some elements of comparative law on good practices and to make recommendations of practices to ensure the protection of stray dogs.

\section{The national legal framework on stray dogs}

\section{II.1. The context of regulating the situation of stray dogs in Romania. The beginning of the end?}

Since the mid-1990s, the Romanian and foreign printed, on-line and audiovisual media regularly reported on the large number of stray dogs on the streets and the problems that have ensued: attacks by stray dogs resulting in serious injuries or even death in some cases; huge indignation caused in Romania and abroad by a number of actions taken by the authorities in order to euthanize the dogs on the streets.

It is obvious that the problem of stray dogs was not unheard-of to the Romanian authorities. However, despite the tragic events that took place during that period (in 1986 10,000 people were bitten by stray dogs, and in $2000,20,000$ people showed up at the AntiRabies Center ${ }^{6}$ ), the authorities did not take any action to manage the problem of stray dogs.

\footnotetext{
${ }^{5}$ We do not intend to address here the issue of acts committed against animals with owner, which is a complex subject, that deserves to be analyzed in an article entirely dedicated to it.

${ }^{6}$ Dan Radu, Octav Ganea, Șeful hingherilor din Capitală: „Bucureștiul este open space. Aici, totdeauna, vor veni câini". Metropola cu 50.000 de câini și patru prinzători. Reportaj Multimedia, published on 23 April 2012, available at https://www.gandul.ro/reportaj/seful-hingherilor-din-capitala-bucurestiul-este-open-space-aicitotdeauna-vor-veni-caini-metropola-cu-50000-de-caini-si-patru-prinzatori-reportaj-multimedia-

8299917\#live close (last accessed on 31 January 2021).
} 
At that time, the Veterinary Sanitary Law no. $60 / 1974^{7}$ was in force and had as subject of regulation the protection of animal health and the prevention of the transmission of diseases from animals to humans. In art. 39 the law offered a legal basis for the creation of specific structures for the control of stray dogs by stating that local authorities were in charge of "organizing the capture and destruction of stray dogs". The law also provided for a sanction for the non-fulfilment of this obligation, by sending to the provisions of art. 248 and $248^{1}$ of the Criminal Code in force at that time. Accordingly, this offence would represent abuse of office against public interests or, depending on the consequences, abuse of office in a qualified form. The first conclusion that clearly emerges from the cited provisions is that at that time it was allowed to kill stray dogs. Secondly, despite the existence of these provisions in Law no. 60/1974, the lack of methodological norms to establish how the capture and killing will be performed, was likely to create the perfect framework for abuse and cruelty in fulfilling the obligations imposed by Law no. 60/1974.

Art. 39 of Law no. 60/1974 was amended on 28 August 1998 to provide that the local authorities were in charge of "organizing the capture of stray dogs and employing, for this purpose, specific techniques authorized by international veterinary norms". Firstly, this amendment represents an evolution from the previous regulation, considering that national authorities are required to comply with the obligation to control stray dogs in compliance with international rules. Secondly, the fact that the obligation to kill stray dogs was no longer expressly provided gave the law an appearance of morality. We will further see in the section dedicated to the analysis of international and European norms what the relevant provisions provide for.

However, despite these regulations, the problem of stray dogs has remained either unresolved or has been solved by employing cruel practices, as evidenced by the materials published in the press at that time related to the management of stray dogs (in 2001-2003, 100.000 dogs were euthanized in Bucharest alone ${ }^{8}$ ).

One of the most famous cases from that time that gave rise to concerns related to the need for special regulation in the field of stray dogs management was that of Georgeta Stoicescu, who on October 2000 was attacked, bitten and knocked to the ground by a pack of around seven stray dogs in front of her home of a residential area in Bucharest. The attack had severe consequences on her health. After unsuccessfully trying to obtain domestic remedies, the victim filed an action with the European Court of Human Rights (the Court) ${ }^{9}$, claiming that the incident and its consequences were due to the authorities' failure to fulfill their obligations to solve the stray dogs problem and to preserve the safety and health of the population. She claimed that the Romanian state did not fulfill its positive obligations under art. 8 of the European Convention on Human Rights (ECHR) to protect her physical and moral integrity and prevent intrusion into her private life. The Court found there has been a violation of art. 8 of the ECHR, based on the following two arguments: firstly, it noted that a national court had already addressed the merits of the applicant's complaints, even if the judgment was quashed for procedural reasons. The national court held that the Animal Control Agency, a public body, had not taken all necessary measures to avoid endangering the lives of the

\footnotetext{
7 Published in the Official Gazette, Part I, no. 136 of 2 October 1974 and republished in the Official Journal of Romania, Part I, no. 251 of 16 December 1991.

${ }^{8}$ Adam Popescu, Şi muşcaţi, şi cu banii luaţi!, published on 26 March 2008, available at https://evz.ro/si-muscatisi-cu-banii-luati-797120.html (last accessed on 31 January 2021).

${ }^{9}$ ECtHR, Georgel and Georgeta Stoicescu v. Romania, no. 9718/03, 26.07.2011.
} 
population and to preserve their health and physical integrity ${ }^{10}$; secondly, the Court observed that apart from arguing that society in general should bear responsibility for the current situation of stray dogs in Romania ${ }^{11}$, the Government has not provided any indication as to the concrete measures taken by the authorities at the time of the incident to properly implement the existing legislative framework (namely Law no. 60/1974) with a view to addressing the serious problem of public health and threat to the physical integrity of the population represented by a large number of stray dogs ${ }^{12}$.

The presentation of the national solutions in the two proceedings brought by the applicant is important for the purposes of the present analysis, especially in order to identify the authority responsible for fulfilling the obligations imposed by the aforementioned domestic legislation. The first action was brought against the Bucharest City Hall and was dismissed on the grounds that it had been lodged against a party who did not have legal capacity as defendant, considering that the Animal Control Agency (ACA), the public body responsible for the management of stray dogs was at that time subordinated to the Bucharest Municipal Council ${ }^{13}$. The second action was brought against the ACA and the Bucharest Municipal Council and was dismissed by the national courts, holding that the Bucharest Municipal Council did not have legal standing as defendant and that ACA was closed down and the control of stray dogs was transferred to the mayor's offices of the six Bucharest districts ${ }^{14}$. Regarding this issue, which the applicant considered it was a violation of art. 6 par. 1 of the ECHR, the Court found a violation of this article, citing two arguments ${ }^{15}$ : firstly, requiring the applicant to identify the authority against which she should bring the action in the context of organizational changes in the management of stray dogs was a disproportionate requirement; secondly, the Court noted that since under the Local Administration Acts that followed in that period (Law no. 69/1991 and Law no. 215/2001), the mayor's offices are the executive bodies of the municipal councils, the latter being in charge of setting up services for stray dogs (according to art. 39 of Law no. 60/1974), the applicant could reasonably believe that the Bucharest Mayor Office had legal standing before a court in a matter concerning the ACA's activity and responsibilities (even more since a paper issued by the ACA had the name of the Bucharest Mayor's Office embossed on it).

It is also important to mention that, when analyzing the case, the European Court of Human Rights noted that in 2001, following the incident in this case, the authorities recognized the special situation of the stray dogs population ${ }^{16}$, which led to the issuance of the Government Emergency Decree no. 155 on the stray dogs management programme ${ }^{17}$. The Decree entered into force on 13 December 2001 and regulated the capture and neutering or euthanasia of dogs.

\footnotetext{
${ }^{10}$ Idem, par. 60.

11 Idem, par. 46.

12 Idem, par. 61.

13 Idem, par. 16.

14 Idem, par. 18.

15 Idem, par. 75.

${ }^{16}$ Idem, par. 57.

17 Published in the Official Journal of Romania, no. 794 of 13 December 2001.
} 


\section{II.2. Animal protection and management of stray dogs are not the same. The chronological development of the relevant regulatory acts}

As we pointed out at the end of the previous section, the regulation of the management of stray dogs was done under the pressure of the tragic events before 2001. In the following, we will present the provisions of the Decree no. 155/2001 and the effects it had on the protection of stray dogs:

- Articles 1 and 2 assigned to the local council the obligation to set up specialized services for the management of stray dogs and employ at least one veterinarian, as well as the obligation to set up shelters for stray dogs;

- Article 4 imposed the obligation to capture stray dogs and shelter them for a period of 7 days, during which, according to article 7, they could be claimed or adopted, otherwise they would be euthanized;

- In article 5 par. 2 the act of euthanasia was defined as "an act of slaughter by rapid, painless procedures of old or sick dogs or which have not been claimed or adopted (...)" and was to be performed only by a veterinarian. Aggressive, chronically ill or incurable dogs could be euthanized immediately after capture.

At the present time it is opportune to emphasize the distinction between the notion of euthanasia and killing of animals: considering the provisions of art. 6 para. 2 of the Decree no. 155/2001 which stipulate that "the killing of dogs by other persons or by other methods than those provided in annex no. 3", we appreciate that the notion of "euthanasia" should only be used with reference to the slaughter of animals by rapid and painless procedures and can only be performed by a veterinarian, and the notion of "killing" or any other synonym will be used in all other cases that do not fall within the notion of euthanasia as defined by art. 6 para. 1 of the Decree no. 155/2001.

- Article 12 imposed on the services for the management of stray dogs the obligation of communicating the number of registered dogs.

As an observation at this point, we recall the previous finding regarding the lack of official statistics related to acts of cruelty against stray dogs and we cite a statistic of the situation of stray dogs in Romania carried out by an online news site ${ }^{18}$. Two conclusions can be drawn from this statistic, namely that in the best scenario the data provided by the mayors or some representatives of the management services of stray dogs are approximate, which offers at least a presumption that registration of stray dogs is made; and worst case scenario case, the obvious conclusion is that the persons responsible for the services for the management of stray dogs do not fulfill their obligation imposed by art. 12 of the Decree no. $155 / 2001$. We have previously stated that this lack of official statistics is a sign of the lack of transparency. We maintain this opinion considering the information mentioned above. In the context of an expressly stated obligation to communicate the number of dogs registered in the services for the management of stray dogs, the presumption of lack of transparency turns into a presumption of illegality.

\footnotetext{
18 Departamentul Corespondenți, SITUATIA câinilor fără stăpân în marile orașe. Zeci de cazuri de persoane mușcate sunt raportate în fiecare lună, published in 5 September 2013, available at https://www.mediafax.ro/social/situatia-cainilor-fara-stapan-in-marile-orase-zeci-de-cazuri-de-persoanemuscate-sunt-raportate-in-fiecare-luna-11292314 (last accessed on 31 January 2021).
} 
- It was established the contraventional liability for the non-fulfillment of the obligations imposed by the provisions of the Decree.

The Decree no. 155/2001 was approved by Parliament under Law no. 227/2002 ${ }^{19}$ which drew the following amendments that are of interest for the purposes of the present article:

- Articles 1 and 2 were amended in order to impose the obligation to establish specialized services for the management of stray dogs and shelters only "as needed", but without regulating the meaning of the latter expression or cases that would require the establishment of services or shelters. It is clear that this amendment to the Decree leaves room for discretionary interpretation and application of the law, favoring abuses by local public authorities.

- Article 4 was amended extending to 14 days the term in which the captured dogs can be sheltered and afterwards euthanized.

Unfortunately, after four years, the term in which the captured dogs can be sheltered was again modified by Law no. $391 / 2006^{20}$, this time being reduced to the one initially provided by the Decree, respectively to 7 days. This change is a big step backwards, and the intention of the authorities to end the lives of stray dogs as soon as possible and to get rid of the burden that the management of stray dogs represents for them is all the more obvious as this new law aimed at a single amendment, that of reducing the term from 14 to 7 days.

In addition, the lack of implementing methodological rules for the application of the Decree since its issuance (these being adopted only 12 years after the issuance of Decree no. 155/2001, 12 years in which the Decree was most likely applied at discretion and erratic) gives rise to a presumption of ignoring the need to clarify the unclear aspects of the Decree no. $155 / 2001$ and implicitly to ignore the importance of reducing the number of stray dogs, improving their health and well-being, reducing risks to human health and preventing aggression against humans and animals.

The first legislative step that aims to protect animals, at least at a theoretical level, was the adoption by Parliament in May 2004 of Law no. 205/2004 on animal protection ${ }^{21}$. The law regulates the necessary measures to ensure the living conditions and welfare of animals irrespective of whether they had an owner, thus establishing a series of rights and obligations resting upon both owners and state authorities.

However, the Law contains in art. 1 para. 2 a provision regarding the management of stray dogs, stipulating that this activity is regulated by a special law. This special law is no other than Decree no. 155/2001. This creates a connection from the very beginning, or rather a separation between the field of animal protection and the management of stray dogs. After the presentation of the main provisions of Law no. 205/2004 and of the amendments brought to Decree no. 155/2001, we will try to answer the question addressed even in the title of this section by identifying the relationship between the two normative acts.

Law no. 205/2004 represented the first regulation that banned and established the contravention liability for the act of ill-treatment and cruelty to animals. We may notice right now that Law no. 205/2004 did not contain any provision on the possibility of euthanizing animals, but the acts of cruelty against animals that lead to killing them were prohibited. In

\footnotetext{
19 Published in the Official Journal of Romania, no. 289 of 29 April 2002.

${ }^{20}$ Published in the Official Journal of Romania, no. 892 of 2 November 2006.

${ }^{21}$ Published in the Official Journal of Romania, no. 531 of 14 June 2004.
} 
relation to the previous statement regarding the correct use of the notion of euthanasia only for cases of slaughter by rapid and painless procedures, it seems rather clear that the ban on killing animals "out of pleasure" does not include the ban on euthanasia. It thus appears that euthanasia was allowed by Law no. 205/2004.

This is also one of the reasons why in 2007 a draft law was initiated to amend Law no. $205 / 2004$. In the explanatory memorandum of the draft law ${ }^{22}$, the initiator motivated the need to amend Law no. 205/2004 because of the wrong way of the authorities to try to reduce the population of stray animals, stating that: "Public money is wasted for the destruction of animals, for stopping the effects and not the cause. There are no preventive measures, that can constitute at the same time, animal protection measures." This legislative initiative mainly aimed to regulate the abandonment of animals; a ban on the euthanasia of dogs and cats, following the laws in Spain and Italy, which prohibit the euthanasia of dogs caught or kept in shelters, with the exception of seriously ill or dangerous animals; it increased the contravention fines provided by law; it established criminal liability in case of committing certain acts determined as crimes.

The law has been promulgated in 2008 (Law no. 9/2008 amending and supplementing Law no. 205/2004 on the protection of animals ${ }^{23}$ ) and brought the following amendments that prove to be important for the purposes of this analysis: euthanasia of dogs, cats and other animals was prohibited, except for animals with incurable diseases established by the veterinarian (art. $7^{1}$ ); among others, cruelty against animals was criminally incriminated, being punished with imprisonment from 6 months to 3 years or with a criminal fine from 1.000 lei to 10.000 lei and the confiscation of animals (art. 23 para. $1^{1}$ and para. 3 let. (c).

A new amendment to the Decree no. 155/2001 took place, which preserved the legislative solution of euthanasia of stray dogs, despite the inadvertence of this solution with that provided by Law no. 205/2004 (amended by Law no. 9/2008).

Thus, in 2011 a new draft law was adopted to amend the Decree no. 155/2001. Among the many changes the choice between "keeping in shelters, returning to the territory or euthanizing" stray dogs was left to the discretion of the authorities (local councils), after consulting the population within the administrative-territorial unit ${ }^{24}$. Basically, the draft law lists the measures that can be taken by public authorities, without establishing an order of their application, being likely to create an unfair institutional framework, an erratic practice and a flagrant violation of animal rights. In addition, the version of the draft law adopted by Parliament differs fundamentally from the initiator's legislative proposal, which expressly prohibited the euthanasia of healthy animals ${ }^{25}$.

This provision has been criticized on grounds of unconstitutionality given the following considerations: "The proportionality of the measure of euthanasia of stray dogs, provided by the Management Law can be viewed from two perspectives: as regards the alleged need for euthanasia, the legal provisions run counter to the constitutional principle of proportionality, since the legislative measure is not proportionate (with what has caused it); from an institutional point of view, the regulation of "democratic" decision-making procedures

${ }^{22}$ Available at http://www.cdep.ro/proiecte/2007/800/70/2/em872.pdf (last accessed on 31 January 2021).

23 Published in the Official Journal of Romania, no. 29 of 15 January 2008.

${ }^{24}$ Art. I.8 from the Law for the amendment and completion of Emergency Government Decree no. 155/2001, available at http://www.cdep.ro/proiecte/2007/900/10/2/sesizarecaini.pdf (last accessed on 31 January 2021 ). 25 See point 6 from the Explanatory memorandum, available http://www.cdep.ro/proiecte/2007/900/10/2/em912.pdf (last accessed on 31 January 2021). 
effectively removes the right to life of stray dogs and leads to a non-unified administrative practice at national level, with each local council having the right to choose the "solution" of euthanasia." 26

The Constitutional Court ruled the law was unconstitutional, noting that "the text of Article I(8) of the Law does not meet the predictability requirements imposed by Article 1(5) of the Constitution. The Court notes that the text of Article I(8) of the Law lays down the envisaged solutions concerning the obligation on the public authorities to deal with the problem of stray dogs without taking account of an order in which they must be applied, so that the public authorities called upon to enforce the criticized law will be put in a position to randomly select one or more of them. (...) The Court observes that the legislator must prioritize these solutions and that the solution of euthanasia of stray dogs should only be applied as a last resort. (...) The Court also notes that, by using an inappropriate legislative technique, the legislator ultimately affected human dignity, an ultimate value provided for in Article 1(3) of the Constitution. Human dignity, in a constitutional sense, entails two inherent dimensions, namely the relationship between people, which concerns the right and the obligation of people to be respected and, in a correlation manner, to respect the fundamental rights and freedoms of their fellow citizens (see, in this respect, Decision no. 62 of 18 January 2007, published in the Official Journal of Romania, Part I, no. 104 of 12 February 2007), as well as the human relationship with the environment, including the animal world, which implies, as far as the animals are concerned, the moral responsibility of the man to care for these beings in a way that illustrates the level of civilization achieved." 27

The resumption of debates on the draft law that was to become Law no. 258/2013 for the modification and completion of the Decree no. $155 / 2001^{28}$ was carried out in the tragic context of the death of lonut Anghel, the four-year-old child bitten by dogs near the Tei Park in Bucharest. The provisions declared unconstitutional by the Constitutional Court Decision no. 1/2012 were amended, setting a 14-day period after the accommodation of dogs in shelters, a deadline within which they can be adopted and only in so far as the dogs are neither claimed nor adopted, they will be euthanized on the basis of a decision issued for each individual dog. The draft law was again criticized for unconstitutionality, mainly for the same reasons as in the previous referral, but also for ignoring the cause of the existence of stray dogs, the signatories of the complaint proposing "the reconstruction of the draft law and the effective regulation of the sterilization solution" ${ }^{\prime 29}$. This time the Constitutional Court declared the law constitutional, noting that "the euthanasia of stray dogs appears as a last resort, after the proper application of all other solutions, in line with the ones retained by the Constitutional Court in Decision no. 1/2012."30

Turning to the relation between the two normative documents under review - Law no. 205/2004 (amended by Law no. 9/2008) and Decree no. 155/2001 in the matter of euthanasia, the unfortunate consequences of inaccuracies between them (the first normative act expressly prohibiting it, while the second normative document allowing it) have been described by the Animal Control Agency: "until the entry into force of Law no. 9/2008, it was permitted to kill all quadrupeds that were not adopted. Currently (27 August 2008), however,

\footnotetext{
${ }^{26}$ See http://www.cdep.ro/proiecte/2007/900/10/2/sesizarecaini.pdf (last accessed on 31 January 2021).

${ }^{27}$ Decision no. 1 of 11 January 2012, published in the Official Journal of Romania, no. 53 of 23 January 2012.

28 Published in the Official Journal of Romania, no. 601 of 26 September 2013.

${ }^{29}$ See http://www.cdep.ro/proiecte/2007/900/10/2/sesizarecc912.pdf (last accessed on 31 January 2021).

${ }^{30}$ See Decision no. 383/2013, published in the Official Journal of Romania, no. 644 of 21 October 2013.
} 
the role of the Animal Control Agency (ASA) is theoretically confined to the collection of dogs, sterilization and offering them for adoption" ${ }^{\prime 31}$. The real problem lies in, as was also described by the initiator of the draft law, ignoring the causes of the problem of stray dogs by trying unsuccessfully to solve the problem by mass killing animals. The solution that both protects animals but also solves the problem was presented by an animal protection foundation in the same article: "There are several hundred dogs in the city's shelters, too little compared to the number on the streets. It is the result of the fact that no unified sterilization program has been carried out, which would have produced results in the not very distant future. And this even it is known that, apart from the fact that they can no longer multiply, sterilized dogs are much quieter and do not represent a real danger. ${ }^{\prime 32}$

Faced with an apparent conflict of laws, the authorities tried to find excuses to further kill the stray dogs, as results from the press statements of a representative of such an authority responsible for the management of stray dogs: "As a counterbalance to this special law and in order to sow confusion in the public space and to give the mayors of the country and the general mayor, in Bucharest, a reason for inaction, the so-called animal lovers, in a perfidious way, also "slipped" the community dogs into a general law on animal protection, i.e. Law no. 9/2008. A law, therefore, of all animals, but other than stray dogs covered by the special law"33. The legal argument put forward by the authorities that allowed them to euthanize stray dogs also after the amendment of Law no. 205/2004 by Law no. 9/2008 was the principle of specialia generalibus derogant. Thus, according to the authorities, even if the general law (Law no. 205/2004) forbids euthanasia, the special law on the management of stray dogs (Decree no. 155/2001) allowed it. This argument was also based on the provisions of paragraph 2 of Article 1 of Law no. 205/2004 which stated that "the management of the stray canine population in Romania shall be regulated by special law".

Further on, we will analyze the two laws in order to show that the solution adopted by the authorities when this conflict of laws was in place is based on the application of "cherry-picking" (defined as the process in which a person chooses the solution he wants, by ignoring the other possible solutions $\left.{ }^{34}\right)$. Thus, we do not deny that the legal argument given by the authorities is valid, but we will show that the authorities chose the argument that best supported their solution, namely the killing of stray dogs, thus ignoring any other possible interpretation of the two normative acts.

A closer analysis of the two normative acts is likely to lead to the enforcement of the provisions of Law no. 205/2004. Article 1 par. 1 of Law no. 205/2004 states that "this Act regulates the measures necessary to ensure the living and welfare conditions of animals with or without keeper". Article 1 par. 2 of Law no. 205/2004 states that "the management of the canine population without owner in Romania shall be regulated by special law". So, from the very beginning we are dealing with two different categories of dogs, namely those with or

\footnotetext{
${ }^{31}$ Streinu Cercel, Hingherii din Capitală, neputincioși în fața a peste 30.000 de câini fără stăpân, published on 27 August 2008, available at http://www.ziare.com/streinu-cercel/bucuresti/hingherii-din-capitala-neputinciosiin-fata-a-peste-30-000-de-caini-fara-stapan-584365 (last accessed on 31 January 2021).

32 Ibidem.

${ }^{33}$ Antoaneta Etves, O lege din 2002 permite eutanasierea maidanezilor, published on 16 January 2012, available at https://evz.ro/o-lege-din-2002-permite-eutanasierea-maidanezilor-961663.html (last accessed on 31 January 2021).

34 See the definition given by Collins Dictionary, available at https://www.collinsdictionary.com/dictionary/english/cherry-pick (last accessed on 31 January 2021).
} 
without keeper, to which Law no. 205/2004 will be applied and the stray dogs to which the Decree no. 155/2001 will be applied. In order to clarify the notion of a dog with a keeper, article 2 of Law no. 205/2004 provides that "for the purposes of this law, the keeper of animals shall mean the owner, the person holding any valid title, and any natural or legal person under whose care the animal is". In view of these clarifications provided by Law no. 205/2004, it is evident that a dog in the public domain is a dog without owner, but once captured by the management services of stray dogs and transported into the shelters of these services (in fulfilling the obligations imposed by article 4 of the Decree no. 155/2001), it becomes a dog with a keeper within the meaning of Law no. 205/2004, as it is under the care of a legal person. At this moment, the dog without owner that has come under the care of the shelter belonging to the management services of stray dogs benefits from the protection provided by Law no. $205 / 2004$, and its holder, i.e. the shelter, is not entitled to euthanize it (article $7^{1}$ of the Law). In addition, it must comply with the obligations imposed by this law and ensure the "living and welfare conditions" detailed in article 5 of the law. ${ }^{35}$

Another problem arises here: What is the situation of dogs without owner killed by authorities in the middle of the street? First of all, since they are not captured by the management services of stray dogs, they do not come under the care of a shelter, so they are not dogs with a keeper. They therefore do not benefit from the protection provided by Law no. 205/2004. They would have become subject of the Decree no. 155/2001 which obliges the authorities (local councils) to build shelters, to shelter in them stray dogs, to euthanize the chronically ill and incurable, after the examination by the veterinarian and to euthanize those who have not been adopted or claimed after the time limit. Therefore, based on the Decree no. 155/2001 stray dogs could not have been euthanized in the street. This is actually one of the cases where article 6 par. 2 of the Decree no. 155/2001 intervenes by prohibiting the killing of dogs by persons other than veterinary surgeons or by means other than those defining euthanasia. This act is sanctioned with a fine, in accordance with article 14 let. $b$ of the Decree no. 155/2001.

Under these circumstances, it is obvious that the authorities have adopted the most favorable solution by choosing to address the so-called solution of the problem of stray dogs by killing them, an approach which, on the one hand, has only temporarily solved the problem of the large number of stray dogs by not identifying and resolving the cause of this very large number and, on the other hand, it constitutes an approach that is completely in contradiction with the principle of animal protection.

Proof of this wrong approach are also the numerous attacks of stray dogs during the period when the two laws were in force in the form analyzed above, as evidenced by the press articles at the time: in March 2008 a teacher from Bucharest was attacked by a dog from the street $^{36}$; in 2010 a woman from Suceava was attacked by six pit-bull half breeds ${ }^{37}$; in 2012 a

\footnotetext{
${ }^{35}$ See also, Dan Talapaga, Pot fi eutanasiați câinii fără stăpân sau nu? Ce lege se aplică, cum și cine a modificato, published on 6 September 2013, available at https://www.hotnews.ro/stiri-esential-15524481-poteutanasiati-cainii-fara-stapan-sau-nu-lege-aplica-cine-cum-modificat.htm (last accessed on 31 January 2021).

${ }_{36}$ Adam Popescu, Profesoară de desen mutilată de maidanezi, published on 24 March 2008, available at https://evz.ro/profesoara-de-desen-mutilata-de-maidanezi-796767.html (last accessed on 31 January 2021).

37 Adam Popescu, Femeie sfâșiată de șase metişi de pitbull, published on 30 March 2010, available at https://evz.ro/femeie-sfasiata-de-sase-metisi-de-pitbull-890958.html (last accessed on 31 January 2021).
} 
woman died after being attacked by a pack of stray $\operatorname{dog}^{38}$.

Eventually, the problem of inadequacies between the two laws has been resolved, so the analysis previously presented has just theoretical interest. On 1 February 2014 Law no. 205/2004 undergone a major modification by implementing Law no. 187/2012 for the implementation of Law no. 286/2009 on the Criminal Code. Article $7^{1}$ is thus amended as follows: "The euthanasia of dogs, cats and other animals carried out in breach of the procedure laid down by law is prohibited." Per a contrario, euthanasia of animals in accordance with the procedures laid down by law was allowed. This way, by sacrificing the protection of animals, the contradiction between Law no. 205/2004 and Decree no. 155/2001 disappears.

A welcomed amendment, but unfortunately with no incidence in the euthanasia of stray dogs, is the amendment of Law no. 205/2004 through Decree no. 175/202039 which created the legislative framework for placing animals in a shelter for a period of 45 days, if they are in a state of danger. To this end, the Animal Police has been established. In view of the above-mentioned arguments for which we consider that Law no. 205/2004 is also applicable in the case of stray dogs, the new amendment of the law also has the effect of better protecting the latter. So, at least theoretically, if the police find a stray dog in danger, they must intervene and place the animal in a shelter for a period of 45 days. Pursuant to article $24^{5}$ par. 5 of Law no. 205/2004 as amended, on expiry of that period, an animal which has been placed in the shelter and not claimed by the holder shall be considered abandoned. It will be interesting to see how the authorities will apply this provision to the hypothesis of stray dogs which by definition are abandoned animals: they will either be accommodated for a period of 14 days (pursuant to article 4 par. 1 of the Decree no. 155/2001) or sheltered for a period of 45 days (pursuant to article $24^{1}$ par. 1 of Law no. 205/2004). Regardless of the solution adopted, the conclusion is the same: at the end of the accommodation period, the dog without owner that has not been adopted will be euthanized.

\section{Overview of the European and international legal framework and examples of solutions identified by other countries}

Following the adoption on 10 September 2013 of Law no. 258/2013 amending the Decree no. 155/2001, the European Commissioner Tonio Borg sent a letter ${ }^{40}$ to Romania on 1 October 2013 to remind it of its international obligations, in particular of the recommendations of the World Organization for Animal Health (OIE) on the management of the stray dog population which state that killing/euthanasia is not an effective method and that it should only be a last resort solution. The letter highlighted the lack of competence of the European Union (EU) in the management of stray dogs, but despite this absence, reference was made to article 13 of the Treaty on the Functioning of the European Union (TFEU) which recognized all animals as "sentient beings".

\footnotetext{
${ }^{38}$ Alina Neagu, Satu Mare: O femeie a murit după ce a fost atacată de o haită de câini fără stăpân, la marginea orașului, published on 30 January 2012, available at http://www.hotnews.ro/stiri-esential-11371886-satu-marefemeie-murit-dupa-fost-atacata-haita-caini-fara-stapan-marginea-orasului.htm (last accessed on 31 January 2021).

39 Published in the Official Journal of Romania, no. 954 of 16 October 2020.

${ }^{40}$ Available at https://ec.europa.eu/archives/commission 2010-

2014/borg/docs/01102013 letter stray dogs.pdf (last accessed on 31 January 2021).
} 
Responding to the numerous complaints about the welfare and management of stray dogs in Romania, also stemming from the amendment of the Decree no. 155/2001, the European Commission (the Commission) published a reply to these complaints in the Official Journal of the European Union ${ }^{41}$ at the end of 2013, pointing out that despite the fact that the welfare and management of stray dogs is an unregulated area at Union level, these competences remain the responsibility of the Member States. The Commission stated that it supports the work of the World Organization for Animal Health on recommendations on the control of stray dogs, stressing the important role of local authorities in the enforcement of legislation on the management of these animals. The Commission supports the OIE recommendations which underline the need for parallel approaches in controlling the stray dog population and call for the killing of animals carried out in an humane manner and only when necessary, since it is not a sustainable strategy if carried out in isolation of other methods. The Commission also stresses that each Member State, as a Member of the OIE, must appreciate which international recommendations are most appropriate in their national context.

Over the time, there have been moves to draw the European Union's attention on the need to regulate at European level the area of management of stray dogs. These movements took the form of written declaration based on the Rules of Procedure of the European Parliament. The Rules of Procedure laid down that a written declaration was a text of no more than 200 words in an area falling within the competence of the European Union. The purpose of the written declarations was to draw attention to issues that might otherwise have been overlooked $^{42}$. We must point out that the institution of written declarations ceased to exist, being removed in the general revision of the Rules of Procedure of the European Parliament, adopted on 13 December 2016.

Given that written declarations represent only the views of their signatories and not the European Parliament, as they are not official documents of the European Parliament, they have no political weight, i.e. they cannot require the Parliament or other EU bodies to take action in the areas covered by the declarations. However, even if written statements are not of a legal nature, with their adoption, the representatives of European citizens have formally recognized the problem of the growing number of stray animals in Europe, calling on the European Commission to become active in this area.

In 2012, given that there is no EU legislation on the protection of pets and stray animals and that some of them become victims of mistreatment and cruelty in many Member States, the European Parliament adopted a resolution on the creation of an EU legal

${ }^{41}$ Available at https://www.europarl.europa.eu/sides/getDoc.do?pubRef=-//EP//NONSGML+WDECL+P6-DCL2006-0031+0+DOC+PDF+VO//EN\&language $=E N$ (last accessed on 31 January 2021).

${ }^{42}$ The Written Declaration on the welfare of stray animals in EU member States, EU accession countries and other European states (2006) - available at https://www.europarl.europa.eu/sides/getDoc.do?pubRef=//EP//NONSGML+WDECL+P6-DCL-2006-0031+0+DOC+PDF+V0//EN\&language=EN (last accessed on 31 January 2021).

The Written Declaration on the welfare of pets and stray animals (2009) - available at https://www.europarl.europa.eu/sides/getDoc.do?pubRef=-//EP//NONSGML+WDECL+P6-DCL-2009-

0012+0+DOC+PDF+V0//EN\&language=EN (last accessed on 31 January 2021).

The Written Declaration on dog population management in the European Union (2011) - available at https://www.europarl.europa.eu/sides/getDoc.do?pubRef=-\%2F\%2FEP\%2F\%2FNONSGML+WDECL+P7-DCL2011-0026+0+DOC+PDF+V0\%2F\%2FEN\&language $=E N$ (last accessed on 31 January 2021). 
framework for the protection of pet animals and stray animals (2012/2670(RSP) $)^{43}$. With this resolution, the European Parliament calls, on the one hand, on the European Union and the Member States to ratify the European Convention for the Protection of pet animals and to transpose its provisions into national legal systems, and on the other hand, invites the Commission to present proposals for an EU legal framework for the protection of pets and stray animals.

The Commission rejected the resolution ${ }^{44}$, arguing that pet animals and stray animals are not governed by the EU Treaties, but are governed by each Member State and by their own animal welfare laws. The Commission has argued that it is unable to propose the adoption of the desired legal framework in EU law, because the Union's powers are governed by the principle of conferral (article 5 of the Treaty on European Union (TEU)) and the competences not conferred on the Union by the Treaties belong to the Member States (article 4 TEU). Thus, the Treaties do not provide a legal basis for the requested rules, which relate to the protection of animal welfare, which fall within the competence of the Member States.

The only international treaty that mentions pet animals is the European Convention for the Protection of Pet Animals (the Convention) adopted by the Member States of the Council of Europe in 1987, to which Romania is a party ${ }^{45}$. The Preamble of the Convention States that "man has a moral obligation to respect all living creatures and bearing in mind that pet animals have a special relationship with man". Article 1 defines the pet animal as being "any animal kept or intended to be kept by man in particular in his household for private enjoyment and companionship". The point 15 let. d from the Explanatory Report to the European Convention for the Protection of Pet Animals states that "the definition of a pet animal covers stray animals and the first generation of animals born of stray animals". Therefore, stray dogs must benefit from the protection of the European Convention for the Protection of Pet Animals.

For the purposes of the present analysis, two articles of the Convention are important: article 11 on the killing of pet animals and article 12 on the reduction of numbers of stray animals. Article 11 under the name "killing" states that this activity can only be carried out by veterinary surgeons or another competent person, precisely because, as the explanatory report shows at point 38, killing of pet animals and stray animals by persons who do not have the necessary skill and knowledge can lead to much suffering. Article 12 provides that when a Party considers that the numbers of stray animals present it with a problem, it shall take the appropriate legislative and/or administrative measures necessary to reduce their numbers in a way which does not cause avoidable pain, suffering or distress. Although article 12 does not impose on public authorities the obligation to capture or kill stray animals, if they decide to do so, they must use humane methods. Instead, Member States are under the obligation to encourage the sterilization of stray animals.

The Constitutional Court of Romania recognized by Decision no. 1/2012 that the euthanasia provided by the Decree no. 155/2001 should be carried out in compliance with the Convention. This was one of the reasons for admitting the exception of non-

\footnotetext{
${ }^{43}$ Available at https://www.europarl.europa.eu/sides/getDoc.do?pubRef=-//EP//TEXT+TA+P7-TA-20120291+0+DOC+XML+V0//RO (last accessed on 31 January 2021).

${ }^{44}$ See http://www.esdaw.eu/uploads/1/0/2/4/10241201/sp 2012 636-0 eu framework.pdf (last accessed on 31 January 2021).

${ }^{45}$ Romania signed the Convention on 23 June 2003. The Romanian Parliament ratified the Convention through Law no. 60/2004, published in the Official Journal of Romania, no. 400 of 5 May 2004.
} 
constitutionality of provisions which did not establish a hierarchy between the methods chosen by the authorities for the management of the stray dog population. For the same reason, in Decision no. 383/2013, the Constitutional Court considered that the new wording of the rule, which established an order of application of methods to reduce the number of stray dogs, euthanasia being the last measure available to the authorities, was constitutional, also respecting the Convention provisions.

The International Organization for Animal Health (OIE) represents the reference organization of the World Trade Organization (WTO) for setting standards in animal health. The 182 Member States and territories ${ }^{46}$ have mandated the organization to take international leadership in animal welfare and, as an international reference organization for animal health, to develop recommendations and guidelines for animal welfare practices. The OIE underlines that it is a body responsible for setting standards and is not responsible for implementing them. ${ }^{47}$

The OIE publishes two codes and two manuals (terrestrial and aquatic) as the main reference for WTO members. The OIE Terrestrial Code has a chapter dedicated to recommendations in matters of stray dog population control ${ }^{48}$. Their purpose, as reflected in the Preamble of the chapter, is to contribute to the management of stray dogs by recommending means in this respect that do not subject animals to unnecessary suffering. The recommendations are based in the following principles (article 7.1.2 and 7.7.1 o the Code): the "five freedoms" (freedom from hunger, thirst and malnutrition; freedom from fear and distress; freedom from physical and thermal discomfort; freedom from pain, injury and disease; and freedom to express normal patterns of behavior); the promotion of responsible dog ownership can significantly reduce the numbers of stray dogs; the control of dog populations has to be accompanied by changes in human behavior to be effective. With regard to the reduction of the number of stray dogs, it is recommended that euthanasia be carried out in conjunction with other measures to limit and control the population and, where euthanasia is necessary, it should comply with the general principles set out in the Code, focusing on the use of practical, rapid and humane methods. Effective legislation, public awareness, education and promotion of these elements are presented as medium and long term solutions for solving the problem of stray dogs (article 7.7.6).

Romania, along with nine other Balkan States, has undertaken the obligation to implement OIE standards at national level by 2025 . This means that Romania has committed itself to reducing the number of stray dogs to an acceptable level by using methods and respecting the principles imposed by the $\mathrm{OIE}^{49}$.

At international level there is also the International Companion Animal Management Coalition $(\text { ICAM })^{50}$, formed by non-governmental organizations in the field of animal protection with a similar vision of their management. As ICAM does not bring together representatives from States but from NGOs, its approach differs from that of the OIE: while the OIE strategies are directed towards authorities, ICAM recommendations focus more on

\footnotetext{
${ }^{46}$ According to https://www.oie.int/about-us/ (last accessed on 31 January 2021).

47 According to http://worldanimal.net/images/stories/documents/Stray control report FINAL.pdf (last accessed on 31 January 2021).

${ }^{48}$ Chapter 7.7., available at https://www.oie.int/index.php?id=169\&L=0\&htmfile=chapitre aw stray dog.htm (last accessed on 31 January 2021).

${ }^{49}$ See https://www.oie.int/doc/ged/D14134.PDF (last accessed on 31 January 2021).

50 See About - ICAM (icam-coalition.org) (last accessed on 13 February 2021).
} 
$\mathrm{NGOs}^{51}$. However, the principles of stray dog management are the same ${ }^{52}$ : management must be humane and ethical, minimizing injury and maximizing benefits for dogs and human communities. Management cannot be considered humane if it includes the nondiscriminatory killing of dogs, the killing of dogs on the street or the use of killing as the sole measure to manage stray dogs. Among the management principles, a great value is given to the causes of the large number of stray dogs and the role people have for the stray dog population of their community.

The aim of presenting these international instruments in the field of animal protection and management of the stray dog population is to show that there are regulations, policies, strategies at regional and international level that can inspire and motivate national policies and legislation. All principles, recommendations and policies presented can provide information that can help develop policies and legislation at national level. Furthermore, organizations developing these policies may also be available to help building a political will so that communities can take such initiatives or receive help to interpret the documents presented. This approach is also taken by the Food and Agriculture Organization of the United Nations (FAO) in a 2011 report on dog population management ${ }^{53}$. FAO states in this report that the relevant regulations and recommendations of international organizations such as the Council of Europe and the OIE must be incorporated into national policies and legislation, and if this is to be possible, it is necessary that policy-makers have the political will to voice the interests of the communities they represent, which is why decision-makers need to be informed.

While respecting the recommendations for good managing of the stray dog population, there are European States that have managed to reduce their number by using humane management methods that offer the greatest possible protection to these animals.

Thus, the Netherlands became the first country in the world without stray dogs and succeeded in this by implementing legislation to protect the welfare of all animals, including stray dogs. The Animal Law of 2011 (in force since 2013) expressly recognizes the characteristic of animals to be "sentient beings" (article 1.3), as also provided for in article 13 of the TFEU. The law states that recognizing the intrinsic value of animals means recognizing the integrity and welfare of animals as sentient beings. Paragraph 3 of article 1.3 establishes the basis for animal care based on the "five freedoms" internationally recognized and stated above. Article 2.1(1) of the Act prohibits causing pain or harming the health and welfare of animals without a reasonable purpose or by exceeding the reasonable character of the purpose. Article 1.4 of the law lays down the task of citizens to care for animals on the basis of the five freedoms, which also extends to the case where a person does not take action when he knows or suspects that this may lead to injuring the animal. Article 8.12(3) and Article $8.12(4)$ of the law states that the violation of anti-cruelty provisions or the obligation to care

\footnotetext{
${ }^{51}$ See Report on the OIE's International Standard on Stray Dog Population Control, published on 12 June 2015, available at http://worldanimal.net/images/stories/documents/Stray control report FINAL.pdf (last accessed on 31 January 2021).

52 See Humane Dog Population Management Guidance realizat de ICAM, updated in 2019, availsble https://www.icam-coalition.org/wp-content/uploads/2019/09/2019-ICAM-DPM-guidance-Interactiveupdated-15-Oct-2019.pdf (last accessed on 31 January 2021).

${ }^{53}$ See FAO. 2014. Dog population management. Report of the FAO/WSPA/IZSAM expert meeting - Banna, Italy, 14-19 March 2011. Animal Production and Health Report. No. 6. Rome, published in 2014, available at http://www.fao.org/3/a-i4081e.pdf (last accessed on 31 January 2021).
} 
is a crime punishable by a fine or imprisonment of up to 6 months. Any act of neglect or cruelty against animals is punishable by a fine of up to 16.000 euros or even 3 years in prison. In order to ensure compliance, a special police division was created in 2011, namely the "Animal Police", which has as primary aim the prevention of cruelty and abandonment of animals. The animal police is responsible for investigating cases involving neglecting the animals and for rescuing them from dangerous situations, including taking any animals without an owner from the street, with citizens even having to alert the authorities if they see a stray $\operatorname{dog}^{54}$. As regards the policy of managing stray dogs, the Netherlands has implemented a national program of compulsory sterilization, which allows for free sterilization or castration of dogs. Another effective measure taken by the authorities is the introduction of high fees for the purchase of pure-bred dogs to encourage the adoption of dogs from shelters. ${ }^{55}$

Sweden recognizes animals as sentient beings. The Animal welfare Law of 2018 is the main legislative act on animal protection. Chapter 1 , Section 1 provides that the animals must be respected. Chapter 2, Section 2 also provides that animals must be allowed to behave "naturally". Section 13 of Chapter 16 of the Penal Code provides that exposure of an animal to suffering by maltreatment, whether intentionally or negligently, is cruelty to animals. The draft animal welfare law states that animal suffering can also be physical and mental. The Animal welfare Law specifies in Chapter 2, Section 1, that "animals must be treated well and protected from unnecessary suffering and diseases". Chapter 10 of the Animal welfare Law regulates the penalties for breaching the provisions of the law that may entail the penalty of the fine or prison for up to 2 years. As regards stray animals, Chapter 2, Section 8 of the Act prohibits the abandonment of animals, which proves the intention of the authorities to promote responsible principles in the field of animal property. In addition, a ban on the abandonment of pet animals indirectly serves to limit the number of animals without owner. Detailed rules on the conditions for keeping dogs and cats have also been issued. Under Regulation 2007:1150 on the supervision of dogs and cats, these animals must be cared for according to their nature without causing injury. Section 2 of that Regulation requires the registration of dogs. It also provides that a person may be declared unable to properly care for a dog, with the consequence of imposing a fine and prohibiting the possibility of obtaining another dog, and if such a person violates this ban, he will be sentenced to fines or prison for up to a year. ${ }^{56}$

The animal welfare legislation in Switzerland is extensive and detailed. Both the Animal welfare Law of 2005 and the Animal welfare Decree of 2020 set basic standards for the care of all animals and for their protection against cruelty. The Decree clearly sets out the behavior to be adopted by animal owners and those responsible for their care. The 2005 Law, while not using the notion of "sentient beings", recognizes the physical and mental health of animals. The use of the word "dignity" suggests the intention to ensure that all animals protected under the law enjoy a good quality of life. Article 4(2) of the law prohibits causing

\footnotetext{
${ }^{54}$ See Animal Protection Index (API) 2020. Kingdom of the Netherlands carried out by World Animal Protection, published in 2020, available at https://api.worldanimalprotection.org/sites/default/files/api_2020 netherlands 0.pdf (last accessed on 31 January 2021).

55 There is Now a Country with No Stray Dogs published on 4 May 2018, available at https://myanimals.com/latest-news/help-them-out/country-no-stray-dogs/ (last accessed on 31 January 2021). 56 See Animal Protection Index (API) 2020. Kingdom of Sweden $r$ carried out by World Animal Protection, published in 2020, available at https://api.worldanimalprotection.org/sites/default/files/api 2020 sweden.pdf (last accessed on 31 January 2021).
} 
pain, suffering or injury to an animal, inducing anxiety or ignoring the animal's dignity in any other way, without justification. It shall be prohibited to abandon, neglect, organize or kill animals. Article 26 of the law stipulates that anyone who mistreats an animal intentionally or negligently or fails to protect its dignity is subject to a fine or prison for up to 180 days. The person convicted of such action may be prohibited from holding another animal. The euthanasia of stray dogs is permitted. ${ }^{57}$

Great Britain was the first country in the world to adopt a legislation on animal protection. The Animal welfare Law of 2006 is currently in force, the aim of which is to regulate relations between humans and domestic animals and to protect them from maltreatment. Section 4(1) of this law prohibits causing unnecessary suffering to an animal by act or omission, where the perpetrator knew or could reasonably be aware that his act or omission is likely to cause suffering. Although the notion "cruelty" is not used, the prohibited conduct includes cruel acts (sections 5 to 8 of the Act), and case-law under the previous animal protection law - which used this notion, is still considered relevant. According to section 149 of the Environmental Protection Act of 1990, local councils are obliged to treat all unaccompanied dogs on the public domain as stray dogs, whether they have collar or have been microchipped. The Council must capture all these dogs, and if they cannot be returned to owners, they will be kept in shelters for a period of 7 days. At the end of this period, dogs may be returned to the territory, accommodated in the shelter or, following a veterinary evaluation, euthanized. ${ }^{58}$

The main conclusions that can be summarized after the presentation of the elements of comparative law in the field of animal protection and the management of stray dogs start from the idea that "the difference between Romania and the other European countries in terms of successfully managing stray dogs does not so much reside in the laws adopted, but in the holistic approach applied" ${ }^{\prime 29}$. Romanian legislation provides, at least theoretically, principles in animal protection and practices for the management of stray dogs, which have proved ineffective over time. The legislation in the countries analyzed, in addition to complying with relevant international standards, puts in place "education of animal owners, mandatory identification and registration, control of pet animals' reproduction, and prevention of abandonment" 60 . In practice, the States analyzed proposed developing practices that would have long-term effect and that would guarantee the protection of animals with and without owner, while Romania has set out to solve the problem of stray dogs in the short term, by means that violate the principles of animal protection.

\footnotetext{
57 See Animal Protection Index (API) 2020. Kingdom of Sweden $r$ carried out by World Animal Protection, published in 2020, available at https://api.worldanimalprotection.org/sites/default/files/api 2020 switzerland.pdf (last accessed on 31 January 2021).

58 See Animal Protection Index (API) 2020. Kingdom of Sweden $r$ carried out by World Animal Protection, published in 2020, available at https://api.worldanimalprotection.org/sites/default/files/api 2020 - uk 0.pdf (last accessed on 31 January 2021).

59 Roxana Pencea, Tudor Brădățan, Stray Dogs in Romania - Policies, legal framework and solutions, January 2015, p. 7.

60 Ibidem.
} 


\section{Final considerations and recommendations}

Starting from the final remarks of the previous section, Romania needs to change its approach to guarantee an effective animal protection.

The last amendment of Decree no. $155 / 2001$ by Law no. $258 / 2013$ - which is also the version currently applicable, indeed provides a legal framework closer to the protection of stray dogs, trying to consider both animal protection and human protection. But, under the current rules, euthanasia will become an inevitable step. The assessment of the unavoidable character of euthanasia is based on several arguments: the very large number of stray dogs in Romania (at the level of 2013 in Bucharest alone there were about 60.000 stray dogs ${ }^{61}$ ) and the very low probability that they will be adopted within 14 days of the capture; the lack of accommodation in public shelters, which will lead to the constant euthanasia of dogs to accommodate other captured dogs; the lack of people's desire to adopt stray dogs, either from a lack of education, empowerment and promotion of animal protection, or because of the perception that people have about the aggressiveness of these animals, a perception influenced by the multitude of cases of attacks by stray dogs, which, in fact, encourages people to solve the problem of inefficient management of stray dogs by killing them themselves ${ }^{62}$.

There is an aspect that is even more damaging to the protection of animals than the euthanasia itself, namely the gradual killing of stray dogs due to inadequate accommodation conditions. The methodological rules for the application of the Decree no. 155/2001 provide that the capture, transport and accommodation of stray dogs must be carried out in compliance with the principles of animal protection (article 12 par. 1 of the Governmental Decision no. $1059 / 2013^{63}$ ), provided for in both national legislation (Law no. 205/2004), as well as in the relevant international regulations, but the situation in the field is quite different. An analysis of public shelters in Romania carried out after 2015 by a non-governmental organization ${ }^{64}$ shows that "sending a dog to a public shelter is a death sentence" because "public shelter is synonymous with killing factory in Romania" given the conditions under which these animals are sheltered. Therefore, not even the sheltering conditions protect animals. And if euthanasia is in some cases allowed by national legislation and international regulations and recommendations, all of these documents require, without exception, compliance with the principles of the protection of animals in the process of capture, transport and accommodation. The methodological norms which impose these principles were only drawn up in 2013, although the Decree no. 155/2001 exists and has been in place since 2001. Thus, if in 2015 when the above analysis was carried out, the public sheltering conditions were described as a death sentence, although the methodological norms requiring

61 Bucureștiul câinilor maidanezi. "Minunea" care a provocat scăderea numărului persoanelor mușcate, published on 9 December 2013, available at https://stirileprotv.ro/special/bucurestiul-cainilor-maidaneziminunea-care-a-provocat-scaderea-numarului-persoanelor-muscate.html (last accessed on 31 January 2021).

${ }^{62}$ Christopher Zara, Romanian Stray Dogs Slaughtered On The Streets As 'Red Card For Romania' Spreads On Facebook published on 11 December 2013, available at https://www.ibtimes.com/romanian-stray-dogsslaughtered-streets-red-card-romania-spreads-facebook-1505630 (last accessed on 31 January 2021).

63 Published in the Official Journal of Romania, Part I, no. 829 of 23 December 2013.

64 LIFE OF A ROMANIAN HOMELESS DOG (1 OF 3$)$ available at https://www.voicefortheneedy.org/en/infographics/dog-life/ (last accessed on 31 January 2021). 
compliance with the principles of animal protection had been in force since 2013 , we presume that before 2013 there was a non-compliance with these principles.

While we agree that it is important to develop a sustainable, long-term strategy to effectively treat the population of stray animals both for the protection of people and for the health and welfare of the animals themselves, at the same time, we believe that the management policy must not cause animal suffering. To achieve this objective, we consider that, firstly, an effective implementation of the rules already in force is necessary, because, as already shown, the legal framework exists and, at least theoretically, ensures the protection of stray dogs. Secondly, we believe there is a need for dissemination, followed by an understanding of relevant international standards and successful practices implemented by other states.

As we have shown, in Western societies where the concept of "dog ownership" prevails, comprehensive programs were designated and implemented that put in place education of animal owners, mandatory identification and registration, control of pet animal reproduction and prevention of abandonment. However, "the mere existence of such stipulations in the law, without an effective and constant implementation through national programs, will not lead to a change in the status quo". 65

${ }^{65}$ Roxana Pencea, Tudor Brădățan, Stray Dogs in Romania - Policies, legal framework and solutions, January 2015, p. 7. 